УДК 81`23: 351

DOI: $10.26565 / 2227-1864-2020-87-13$

\title{
Spin Doctoring in modern political discourse: linguistic aspect
}

\author{
Anastasia Volodymyrivna Kovalevska \\ PhD in Philology (Candidate of Philological Sciences), \\ Associate Professor of Ukrainian and Foreign Languages Department, \\ Odesa Regional Institute for Public Administration \\ of the National Academy for Public Administration \\ under the President of Ukraine (22 Genuezka St., Odessa, Ukraine); \\ e-mail: ana.kovalevskaya@gmail.com; https://orcid.org/0000-0002-1031-5546
}

\begin{abstract}
In the article, the realization of verbal influence (also known as suggestion) phenomenon in political discourse is considered. This concept is defined as a whole combined image of the text itself and emotions of its recipient and addressee,including the peculiarities of perception, external and internal circumstances, its pragmatic and linguistic aspects, etc, and is aimed at a a political subject's influencing a political object. Usually, political discourse and its immanent influential properties are researched from the standpoint of Psychology, Communicative Linguistics, Pragmalinguistics, Political Linguistics and other related sciences, but the author proposes to involve Neurolinguistic Programming as a modern science which deals with analyzing the peculiarities of perception, processing and generation of information and its transformations from deep thought structures to superficial speech; as well as Spin-Doctoring, an ultramodern complex discipline aimed at correcting the negative image of the event in the media after its has already happened or right before its manifestation, which is impossible without the involvement of language techniques to influence the recipient or a group of them. In order to fully research the political discourse, which in the network of this article is represented by the political speeches of the leaders of Ukraine, USA, France, Spain, Italy, Canada, Germany, the author involves both the basic Spin Doctoring techniques of political discourse correction ( negative information delay, ambiguous informing, focus switch, interspersing the artificial situations with elements of naturalness, and the technique of controlled information leaks and preparation for events expectations); and the NLP paradigm meta- and Milton-model analysis text having been utilized in order to isolate the actual linguistic influential patterns (markers of language metamodel processes, simple, complex and indirect inductions). The analysis details the available information on the peculiarities of implementing and enhancing the linguistic influence within the political discourse, as well as outlines the crucial next steps in the further researches on this topic, especially ones in the field of Ukraine's state information security, which is a particularly important aspect of the state's modern information during hybrid wars. Keywords: Spin Doctoring, Neurolinguistic Programming, NLP, suggestion, language metamodel, language Milton-model, suggestive text, politics, discourse, techniques of influence, state information policy
\end{abstract}

Ковалевська А. В. Спін-докторінг в модерному політичному дискурсі: лінгвістичний аспект

У статті розглядається феномен сугестивності у контексті модерного політичного дискурсу як комплексного поєднання тексту й емоцій реципієнта та адресанта, що містить особливості сприйняття, зовнішні та внутрішні обставини, його прагматичний та лінгвістичний аспекти тощо, і $€$ орієнтованим на здобуття та утримання влади через вплив політичного суб'єкта на політичний об'єкт. У сучасній науковій парадигмі політичний дискурс та його інгерентну сугестивність досліджують із позицій комунікативної лінгвістики, прагмалінгвістики, політичної лінгвістики, теорії мовленнєвх актів та інших дотичних наук, у статті ж для оптимізації вивчення цього феномену із власне лінгвістичної, а радше лінгвосугестивної точки зору запропоновано залучити до аналізу нейролінгвістичне програмування як новітню науку, скеровану на оптимізацію спілкування через вивчення особливостей сприйняття, обробки та породження інформації та її перетворень з глибинних мисленнєвих структур на поверхневі мовленнєві; а також спін-докторінг, ультрановітній науковий напрям, скерований на коригування негативного загального образу події в ЗМІ після отримання нею розвитку, який відрізняється від початково запланованого, а цього майже неможливо досягти без залучення мовних технік упливу на реципієнта чи групу реципієнтів. Для аналізу політичного дискурсу, репрезентованого в рамках даного дослідження політичними промовами очільників України, США, Франції, Іспанії, Італії, Канади, Німеччини, залучено як власне базові техніки корекції політичного дискурсу, запропоновані та розроблені в рамках спін-докторінгу (запізнення «поганої» інформації, неоднозначне інформування, зміна фокусу, вкраплення елементів природності до штучних ситуацій та техніку контрольованого витоку інформації й підготовки очікування подій), так і верифікований у сфері НЛП мета- і Мілтон-модельний аналіз тексту для виокремлення власне лінгвістичних сугестивних патернів (маркерів процесів метамоделі мови, простих, складних та непрямих індукцій). В результаті аналізу деталізовано та комплексно доповнено уже наявні дані про особливості реалізації мовної сугестивності в рамках політичного дискурсу, а також окреслено наступні кроки розвитку досліджень цього феномену, який є вкрай важливим аспектом державної інформаційної політики, особливо в умовах гібридних воєн.

Ключові слова: спін-докторінг, нейролінгвістичне програмування, НЛП, сугестія, метамодель мови, Мілтон-модель мови, сугестивний текст, політика, дискурс, техніки впливу, державна інформаційна політика

Ковалевская А. В. Спин-докторинг в современном политическом дискурсе: лингвистический аспект

В статье рассматривается феномен суггестии в контексте современного политического дискурса как комплексного сочетания текста и эмоций реципиента и адресанта, содержащий особенности восприятия, внешние и внутренние обстоятельства, его прагматический и лингвистический аспекты и т. д., и ориентирован на получение и удержание власти путем влияния политического субъекта на политический объект. В современной научной парадигме политический дискурс и его ингерентную суггестивность исследуют с позиций коммуникативной лингвистики, прагмалингвистики, политической лингвистики, теории речевых актов и других смежных наук, в статье же для оптимизации изучения этого феномена с

(C) Ковалевська А. В., 2020 
собственно лингвистической, а скорее лингвосуггестивной точки зрения предложено привлечь к анализу нейролингвистическое программирование как новую науку, направленную на оптимизацию общения посредством изучения особенностей восприятия, обработки и порождения информации и ее преобразований из глубинных мыслительных структур в поверхностные речевые; а также спин-докторинг, ультрановое научное направление, направленное на корректировку отрицательного общего образа события в СМИ после получения им развития, отличающегося от первоначально запланированного, а этого почти невозможно достичь без привлечения языковых техник влияния на реципиента или группу реципиентов. Для анализа политического дискурса, представленного в рамках данного исследования политическими речами руководителей Украины, США, Франции, Испании, Италии, Канады, Германии, привлечены как собственно базовые техники коррекции политического дискурса, предложенные и разработанные в рамках спин-докторинга (запаздывание «плохой» информации, неоднозначное информирование, изменение фокуса, вкрапления элементов естественности в искусственные ситуаций и техники контролируемой утечки информации и подготовки ожидания событий), так и верифицированный в сфере НЛП мета- и Милтон-модельный анализ текста для выделения собственно лингвистических суггестивных паттернов (маркеров процессов метамодели языка, простых, сложных и непрямых индукций). В результате анализа детализированы и комплексно дополнены уже имеющиеся данные об особенностях реализации языковой суггестивности в рамках политического дискурса, а также обозначены следующие шаги развития исследований этого феномена, который является крайне важным аспектом государственной информационной политики, особенно в условиях гибридных войн.

Ключевые слова: спин-докторинг, нейролингвистическое программирование, НЛП, суггестия, метамодель языка, Милтон-модель языка, суггестивный текст, политика, дискурс, техники влияния, государственная информационная политика

Discourse is usually defined as "speech immersed in life", ie a complex gestalt of text and emotions of the recipient and addressee, features of perception, external and internal circumstances, its pragmatic and linguistic aspects, etc., because "the study of discourse can not be limited to direct analysis of language use without taking into account the purpose or functions that are realized in the process of human activity" [12, p. 1], and should be as anthropo- and communicative-centric as possible. F. Batsevich defines discourse as "a type of communicative activity, an interactive phenomenon, a speech flow that has different forms of expression, occurs within a specific channel of communication, is regulated by the strategies and tactics of the participants; synthesis of cognitive, linguistic and extralinguistic factors, which are determined by specific areas of life, depending on the subject of communication, and results in forming various speech genres" [2, p. 138], emphasizing that discourse is "a living communication,... cognitivespeech and interactive phenomenon with all the relevant components of communication" [1, p. 12].

V. I. Karasyk, researching discourses in the paradigm of sociolinguistics, divides them into personal (personality-oriented) and institutional (status-oriented) [5, p. 208]. Institutional types of discourse, also called sectoral, are differentiated according to the sphere of social activity in which they are implemented, and are usually divided into political, diplomatic, administrative, legal, military, pedagogical, religious, mystical, medical, business, advertising, sports, scientific, stage, mass information ones [5, p. 208]. N. V. Kondratenko defines political discourse as "a concrete manifestation of political communication, which involves the actualization of a political text in a communicative act of interaction between a political subject and a political object" [7, p. 12]. Political discourse aims to "influence the formation of mass opinion, the conquest and retention of power" [4, p. 125], its leading function being the suggestive, ie influential one, because its main purpose is to convince recipients to support a particular candidate or party.
Political discourse and its immanent suggestiveness are usually studied from the standpoint of Communicative Linguistics, Pragmalinguistics, Political Linguistics and other adjacent sciences, but in order to optimize the study of this phenomenon from a linguistic point of view we propose to enrich the analysis with utilizing Neurolinguistic Programming as a brand new science aimed at "optimization of communicative processes and based on in-depth study of subjective reflections, analysis and identification of components of the inner world and the ability to construct positive models of communicative behavior" $[6, \mathrm{p}$. 32] and is a "powerful scientific field that contains a detailed methodological apparatus and a system of practical techniques and technologies that can relate to the neurophysiological mechanisms of influence on the cognitive and psycho-emotional sphere of the individual" [14, p. 186] (namely, the language metamodel which describes "the transformation of the deep structure of human experience into a predetermined surface structure" [10, p. 152]; and language Milton-model, which is functionally inverted to the language metamodel, and is aimed not at optimizing communication and speech concretization, but at activating communicative suggestion aimed at initializing the activity of the subconscious, characterized by increased semantic diffusion). On top of that, we propose to enhance the analysis by involving the core provisions of Spin Doctoring used due to the fact that it is defined as "a form of propaganda ensuring election campaigning in the name of suggestion" [13, p. 358], and often aimed at a certain adjustment of the negative gestalted image of the event in the media after its development, which differs from the one originally having been planned. In order to achieve such "correction", it is obvious that "policymakers should consider implementing auxiliary measures" [19, p. 1237], so it is certainly necessary to involve complex verbal and nonverbal techniques of influence, each of which has its own linguistic indicators, which determines their high suggestive potential, and therefore the inclusion of these techniques' indicators into the analysis of political discourses, inner influential potential being 
their core characteristic, which emphasizes the relevance of our work aimed at forming a method of Spin Doctoring analysis of suggestive political discourses. In order to achieve this goal, it is necessary to perform the following tasks: to characterize Spin Doctoring as an ultranew field of the political discourse influential components research; identify the main techniques of Spin Doctoring used within the political discourse; to analyze these techniques from the standpoint of the NLP language metamodel. Today's political discourse as an array, which, given the specifics of its functioning in today's non-democratic space, is characterized by immanent cross-suggestiveness and pathogenicity is the object of our research; and the actual linguistic features of political discourse as a tool for the realization of its programmed suggestibility is the subject. The factual data of the study, having been recorded during 2006-2020, are speeches of the political leaders, considering the importance of such arrays, given the institutional nature of political discourse (about 500 speeches).

It should be noted that the techniques used in the paradigm of Spin Doctoring are focused on activating right-hemispheric, focused on appealing to the emotional rather than rational component, and, for example, the American researcher Drew Westen argues that, in election campaigns, "the emotional component is exclusively involved ... namely, the degree of emotional support allows better prediction of election results" $[11 ; 15 ; 18]$, and maximizing the emotionality of discourse always results in minimizing its rationality, which explains the sharp suggestiveness of Spin Doctoring contexts. The job of a Spin-Doctor is to "unfold" the event in a negative situation and crisis context in such a way that the consumer moves away from the negative assessment of the event offered to him in the media space. Or at least, such a negative assessment is significantly mitigated" [9], and thus create not just a spin, but a construction of meaning [4].

American political consultant, psychologist and political activist J. J. Rendón emphasizes the importance of such components of the crisis communication plan as: target audiences; required message types; messenger; message delivery system, the key of which, without diminishing the importance of each component, we name the message, because it is the focus of the Spin Doctoring campaign and contains its main provisions, which must be communicated to the target audience $[16 ; 17]$.

Given the specificity of Spin Doctoring as one of the main tools of today's political counseling, most of its techniques are complex and aimed mainly at adjusting and influencing the situation as a whole, including all extracurricular factors, so we, given the linguistic-centric nature of our work, will focus on the linguistic aspects of these techniques analysis.

Researchers [3;9] distinguish such basic types of Spin Doctoring techniques as:

1. Delaying "bad" information - delay of information that is negative, unfavorable for the addressee, which allows not only to prepare public opinion and expectations for its appearance, but even to avoid its disclosure in some cases, delaying time in the interests of the addressee. Effectiveness of this technique is partly explained by the communicative law of accelerated dissemination of negative information, since "people quickly accept positive as normal and cease to discuss it" [2, p. 37-42]. On the other hand, given the activity of another law of communication - the self-emergence of information (according to it, "in case of lack of information in a certain group of communication, information is selfgenerated in the form of rumors. Once born, they can cause other rumors" [2, p. 37-42]) - such a delay should not be too long so that the result does not become the exact opposite of what has been planned.

Having analyzed the political advertising campaigns, as well as official speeches of politicians, we came to the conclusion that the actual linguistic indicators of the implementation of this technique are as follows:

a) presuppositions of the NLP language metamodel distortion process, expressed by temporal adverbs and ordinal numbers, eg: "We'll talk about it the next time" (V. Zelensky, 1+1 Channel, 2020); "You're asking this question for the second time, then talk it over later" (D. Trump, NBC Channel, 2018);

b) less often - markers of simple induction of past trance states of the language Milton-model, eg: "Remember, you already talked about it when it was still not so difficult" (V. Zelensky, 1+1 Channel, 2019); "Remember, that was the case under the last president" (V. Zelensky, ICTV Channel, 2019);

c) less often - markers of simple induction of ordinary trance states of the language Milton-model, eg: "Think, remember how you woke up in the morning, drank coffee, came here in a good moodand here you go and ask this" (V. Zelensky, 1+1 Channel, 2020); "You don't have to think about these problems, let everything be fine with you, it's my job" (D. Trump, CNN Channel, 2018);

d) even less often - markers of the built-in commands of the language Milton-model, eg: "I think, what would you actually like? Because this question clearly shows that something is wrong here" (V. Zelensky, 1+1 Channel, 2019).

2. Ambiguous information: a super-negative message could be superimposed on the same superpositive, thus creating "a difficult situation for the recipient of two sets of information, because he must make an unambiguous decision in an ambiguous, artificially created situation" [9], and thus the negativity of the initial message is at least reduced, and at most it is completely neutralized.

Having analyzed the political advertising campaigns, as well as official speeches of politicians, we came to the conclusion that the actual linguistic indicators of the implementation of this technique are as follows:

a) non-specific lexis of the NLP language metamodel deletion process, expressed by adjectives 
and pronouns, less often by nouns, eg: "Yes, it was a bad idea, and yes, I understand it, but I promise to pay these salaries" (V. Zelensky, 1+1 Channel, 2020); "It's awful and doesn't do me any honor, but look what I'll do to make amends" (V. Zelensky, Novy Channel, 2019);

b) less often - nominalizations of the NLP language metamodel deletion process, eg: "This is, of course, our fig-up, and this choice isn't really a good one, but the correction will be ours" (V. Zelensky, 1+1 Channel, 2019); "My choice is to make unpopular decisions and then let everyone know that I will make them right" (V. Zelensky, 1+1 Channel, 2019);

c) markers of the truisms complex induction of language Milton-model, eg: "Many people say that the wall on the border with Mexico is not needed, but I just want security for my citizens!" (D. Trump, CNN Channel, 2018); "There is an opinion that the gas pipeline will harm the environment. And there is an opinion that Americans need to live on something!" (D. Trump, CNN Channel, 2018);

d) less often - markers of complex induction of pattern disruption of the language Milton-model (which performs the function of maximum contrasting), eg: "Well, yeah, I've f***ed up, so what now? I've $f^{* * * e d}$ up, and I will make it right" (V. Zelensky, 1+1 Channel, 2019).

The scheme of text construction in the case of the strategy of ambiguous information involves the transfer of attention from the negative action of the information object to its positive effect in order to create a certain perceptual balance within the system.

3. Distraction (focus shift) a technique of shifting the focus from a real fact or event or to another event (usually with a connotation different from the first), or to versions or causes of the main event, or to a concomitant or artificially created one that can "draw" audience's attention onto itself, thus giving the spin-doctor a chance to make appropriate communication adjustments to cover the main event about the alleged existence of similar facts in other countries. G. Pocheptsov singles out the following tools used to shift the focus: daily (tactical) ones: car accidents, explosions, natural disasters; long-term (strategic) ones: flu epidemic, cholera [8]. The scientist notes that "the population receives television "antidepressants" in the form of humor, pop or social gatherings. Then it relaxes and forgets about everything else. Similarly, the population receives a television "speed drugs" in the form of accidents, explosions, floods (and understands that everything could have been worse, so evaluates their own context more positively - A.K.). And also forgets about everything. But both are a substitute (natural or artificial) for interest in political or economic issues. And thanks to the constant quarrels over "the freedom of speech", a stable immunity against such issues is developed" [8], which makes this technique so effective. Thus, within this technique, there are two ways to introduce the desired interpretation: by creating a text (creating a new event that would attract much more attention), or by creating a context (correlated with the influential reframing technique to create a "different view" on the same event), and G. Pocheptsov notes that the text can change "+" to "_.", or vice versa. The context works more carefully: it translates "--." into "_" or "+" into “++" [8].

Having analyzed the political advertising campaigns, as well as official speeches of politicians, we came to the conclusion that the actual linguistic indicators of the implementation of this technique are as follows:

a) non-specific lexis of the process of the NLP language metamodel deletion process, expressed by adjectives and pronouns, less often by nouns, eg: "Yes, what I did was a bad idea, and yes, I understand it, but I promise to increase your salaries" (V. Zelensky, 1+1 Channel, 2020); "It's awful and doesn't do me any honor, but look what they did" (V. Zelensky, 1+1 Channel, 2020);

b) less often - nominalizations of the NLP language metamodel deletion process, for example: "This is, of course, our fig-up, but his choice isn't cool either" (V. Zelensky, 1+1 Channel, 2019); "My choice is to make unpopular decisions, but discussing the actions of the opposition is also interesting" (V. Zelensky, 1+1 Channel, 2020);

c) markers of truisms complex induction of language Milton-model, eg: "Many people say that a wall on the border with Mexico is not needed. Oh well. Of course. But the opposition itself pays them for this, so to speak!" (D. Trump, CNN Channel, 2018); "There is an opinion that the gas pipeline will harm the environment. This is the opposition's opinion. And the opposition has a lot of human rights violations, but for some reason you do not pay attention to it" (D. Trump, CNN Channel, 2018);

d) less often - markers of pattern disruption complex induction of the language Milton-model (which perform the function of maximum contrasting), eg: "Yes, I was wrong here. Haven't you ever been wrong? Go $f^{* * *}$ yourself with your criticism!" (V. Zelensky, 1+1 Channel, 2019);

e) less often, markers of truisms complex inductions of language Milton-model (which perform the function of maximum contrasting), eg: "Yes, I was wrong here. But everyone is wrong sometimes. Let's talk about something else?" (V. Zelensky, ICTV Channel, 2020).

The scheme of text construction in the case of the focus shift technique involves shifting attention from the negative effect of the information object to an even more negative action of the competitor (this is characterized by the sub-technique of parallel building of "profitable" negative) to create a certain external perceptual balance, or other action not related to the object in principle, but which will cause the audience's necessary emotion. The subtechnique of reinterpretation of one's negative situation is the second focus change sub-technique, the main meaning of which is to create, generate a positive context for a negative event, which is 
maximally correlated with the above-mentioned data by creating a context for the desired interpretation.

4. Incorporating elements of naturalness into artificial situations - a technique aimed at providing a deliberately artificial, planned and programmed situation that has a high degree of formalization with the signs of naturalness to optimize its perception by the audience, since the more recipients identify a high-ranking official with themselves, the more positively they will perceive the information provided by them.

Having analyzed the political advertising campaigns, as well as official speeches of politicians, we came to the conclusion that the actual linguistic indicators of the implementation of this technique are as follows:

a) presuppositions of distortion process of the NLP language metamodel, most often expressed by adjectives and pronouns, less often by nouns, eg: "I am not only the President. I'm a simple guy from Kryvyi Rih" (V. Zelensky, 1+1 Channel, 2020); "I'm just a Frenchman, just like you" (E. Macron, France3 Channel, 2020);

b) comparative constructions of deletion process of the NLP language metamodel, eg: "Yes, I am the president, but I am the same as you" (E. Macron, TV5 Monde Channel, 2019); "He is the most Ukrainian President” (V. Zelensky, STB Channel, 2019);

c) markers of the truisms complex induction of language Milton-model, eg: "The president must be the President. But also a father, and a son, and a husband as well"(V. Zelensky, 1+1 Channel, 2020); "Do you know what? I've gotten so tired during all this time. Being in power is very difficult";

d) less often - markers of pattern disruption complex induction of the language Milton-model (which perform the function of maximum contrasting), eg: "I'm not a kid to you! I am the President! I'm not a sucker!” (V. Zelensky, 1+1 Channel, 2020); “Get out, robber!” (V. Zelensky, 1+1 Channel, 2020).

5. Techniques of controlled information leakage and preparation of anticipation of events, where the first is used "for the purpose of probing public opinion on a particular problem or issue, in preparation for a particular political action, a particular action of the government .... and the negative reaction of society to information inflow always allows to "refute" it, writing off to the "conjectures of journalists" [3, p. 200]; and in the second, "it is not the event itself that is being prepared, but the expectations of its audience, it allegedly offers what to do in advance in the case of an event" [3, p. 200].
In our opinion, the similarity of these two techniques, which makes it possible to combine them into one, is to provide the audience with pre-prepared information about a particular event / politician, this data already having the maximum suggestive component aimed at subconsciously forming a certain opinion in the recipient on this occasion; the difference is that, in the technique of controlled information leakage, the data is provided on behalf of a reliable but anonymous source, but its anonymity in no way diminishes the weight of the information provided by it; and in the implementation of the expectations preparing technique, the rumors the spin-doctor spreads are the main source of data, and there is no way they could be interpreted as official credible information.

Having analyzed the political advertising campaigns, as well as official speeches of politicians, we came to the conclusion that the actual linguistic indicators of the implementation of this technique are as follows:

a) markers of the truisms complex induction of language Milton-model, eg: "Many colleagues say we have to wait for the revolution. Let's see, let's see" (V. Zelensky, 1+1 Channel, 2019);

b) judgments of deletion process of the NLP language metamodel, eg: "Most likely, Odessa will be in the red zone tomorrow" (Y. Stepanov, 1+1 Channel, 2020);

c) markers of the citation complex induction of language Milton-model, eg: "Churchill also said that if you want peace, you must prepare for war" (B. Johnson, Channel 4, 2019); “As Taras Shevchenko wrote, evil people will wake Ukraine up, after having robbed it" (P. Poroshenko, 1+1 Channel, 2019).

We believe that since our proposed linguistic algorithm of Spin Doctoring of political discourse analysis combines a comprehensive scientific approach in the latest sciences such as Neurolinguistic Programming, Suggestive Linguistics and Spin Doctoring itself, it will make it possible not only to identify the dominant strategies for the formulating these pathogenic texts and the deep mechanisms of their construction, but also - in the future - ways to counter information wars represented by such texts, which will serve not only to deepen the relevant provisions of NLP, Suggestive Linguistics and Psycholinguistics, but also in the possible formation of appropriate planning decisions in the field of Ukraine's state information security, which is a particularly important aspect of the state's modern information during hybrid wars, and maximally illustrates the prospects of further developments in this scientific field.

\section{Література}

1. Бацевич Ф. С. Нариси з лінгвістичної прагматики: монографія. Львів: ПАІС, 2010. 336 с.

2. Бацевич Ф. С. Основи комунікативної лінгвістики: підручник. Київ: Академія, 2004. 344 с.

3. Васильева М. М. Связи с общественностью в органах власти: учебник для академического бакалавриата. 2 изд., перераб. и доп. Москва: Издательство Юрайт, 2019. 366 с. 
4. Жибак Д. М. До питання особливостей та функцій політичного дискурсу. Науковий вісник Міжнародного гуманітарного університету. Сер.: Філологія. 2016. № 29, Том 1. С. 124-126.

5. Карасик В. И. Языковой круг: личности, концепты, дискурс. Волгоград: Перемена, 2002. 477 с.

6. Ковалевська Т. Ю. Комунікативні аспекти нейролінгвістичного програмування: монографія. Одеса: Астропринт, 2001. $344 \mathrm{c}$.

7. Кондратенко Н. В. Український політичний дискурс: текстуалізація реальності: монографія. Одеса: Чорномор'я, 2007. $156 \mathrm{c}$.

8. Почепцов Г. Комунікативні операції вчора й сьогодні. URL: https://ms.detector.media/manipulyatsii/post/9425/2011-06-12-komunikativni-operatsii-vchora-i-sogodni/ (дата звернення: 18.11.2020).

9. Почепцов Г. Спин-доктор и его работа: нетрадиционные методы управления информационным пространством. URL: $\quad$ https://detector.media/community/article/1945/2001-11-30-spin-doktor-i-ego-rabota-netraditsionnye-metodyupravleniya-informatsionnym-prostranstvom/ (дата звернення: 18.11.2020).

10. Смит С. Жесткая книга о том, как убедить, загипнотизировать, заставить кого угодно. Маленькая книга сильнейших примов гипноза и воздействия. Москва: АСТ, 2010. 224 с.

11. Brader Ted. The Political Brain: The Role of Emotion in Deciding the Fate of the Nation - By Drew Westen. Political Psychology. 2008. Volume 29, Issue 4. Pp. 623-627 https://doi.org/10.1111/j.1467-9221.2008.00656.x.

12. Brown G. Discourse Analysis. Cambrige: Cambrige Univ. Press, 1983, 288 p.

13. Ciftci D. Political Marketing and New Media Election Campaigning: The Application of North Cyprus 2018 General Elections. Handbook of Research on New Media Applications in Public Relations and Advertising. Cyprus: Near East University, Department of Journalism, Faculty of Communication. 2020. Pp. 355-380.

14. Kovalevska, T., \& Kovalevska, A. Utilizing the Neurolinguistic Programming Technologies in Foreign languages Teaching Practice in Ukrainian Universities. Arab World English Journal: Special Issue on English in Ukrainian Context. 2020. Pp. 184-193. DOI: https://dx.doi.org/10.24093/awej/elt3.16.

15. Owen Lord. Swaying the swingers: how neuroscience influences voting behaviour. Brain. 2008. Volume 131, Issue 2. Pp. 591-595 https://doi.org/10.1093/brain/awm330.

16. Pinza Mariela \& Flax Sabrina. Marketing político. Durán Barba y JJ Rendón, radiografía de dos asesores clave en la construcción de los liderazgos de las derechas del siglo XXI. 2005. URL: https://www.celag.org/wpcontent/uploads/2015/08/Documento-4-marketing-pol\%C3\%ADtico.pdf (дата звернення: 18.11.2020).

17. Rendón J. J. Power of One: Power of one: JJ Rendon at TEDxUNPlaza 2013. 2013. URL: https://www.youtube.com/watch?v=o7k2icowDN8 (дата звернення: 18.11.2020).

18. Victoroff Jeff. Drew Westen: The Political Brain: The Role of Emotion in Deciding the Fate of the Nation Bryan Caplan: The Myth of the Rational Voter: Why Democracies Choose Bad Policies. Democracy and Security. 2009. 5:2. Pp. 193-197, DOI: 10.1080/17419160902973594

19. Underwood D., Sun S. \& Welters R.A.M.H.M. The effectiveness of plain packaging in discouraging tobacco consumption in Australia. Nat. Hum. Behav. 2020. 4. Pp. 1273-1284. https://doi.org/10.1038/s41562-020-00940-6.

\section{References}

1. Batsevych, F. S. (2010). Narysy z linhvistychnoi prahmatyky: Monohrafiia [Essays on linguistic pragmatics: Monograph]. Lviv: PAIS [in Ukrainian].

2. Batsevych, F. S. (2004). Osnovy komunikatyvnoi linhvistyky: pidruchnyk [Fundamentals of communicative linguistics: a textbook]. Kyiv: Akademiia [in Ukrainian].

3. Vasil'eva, M. M. (2019). Svjazi s obshhestvennost'ju v organah vlasti: uchebnik dlja akademicheskogo bakalavriata. 2 izd., pererab. i dop. [Public Relations in Government: A Textbook for Academic Bachelor's Degree. 2nd ed., Rev. and add.]. Moskva: Izdatel'stvo Jurajt [in Russian].

4. Zhybak, D. M. (2016). Do pytannia osoblyvostei ta funktsii politychnoho dyskursu [On the question of features and functions of political discourse]. Naukovyi visnyk Mizhnarodnoho humanitarnoho universytetu. Ser.: Filolohiia. №29, Vol 1. 124-126 [in Ukrainian].

5. Karasik, V. I. (2002). Jazykovoj krug: lichnosti, koncepty, diskurs [Language circle: personalities, concepts, discourse]. Volgograd: Peremena [in Russian].

6. Kovalevska, T. Yu. (2001). Komunikatyvni aspekty neirolinhvistychnoho prohramuvannia: monohrafiia [Communicative aspects of neurolinguistic programming: Monograph]. Odesa: Astroprynt [in Ukrainian].

7. Kondratenko, N. V. (2007). Ukrainskyi politychnyi dyskurs: tekstualizatsiia realnosti: monohrafiia [Ukrainian political discourse: textualization of reality: monograph]. Odesa: Chornomoria [in Ukrainian].

8. Pocheptsov, H. (2011). Komunikatyvni operatsii vchora y sohodni [Communicative operations yesterday and today]. URL: https://ms.detector.media/manipulyatsii/post/9425/2011-06-12-komunikativni-operatsii-vchora-i-sogodni/ (last access: 18.11.2020) [in Ukrainian].

9. Pocheptsov, H. (2011). Spin-doktor i ego rabota: netradicionnye metody upravlenija informacionnym prostranstvom [Spin doctor and his work: non-traditional methods of information space management]. URL: https://detector.media/community/article/1945/2001-11-30-spin-doktor-i-ego-rabota-netraditsionnye-metody-upravleniyainformatsionnym-prostranstvom/ (last access: 18.11.2020) [in Russian].

10. Smith, S. (2010). Zhestkaja kniga o tom, kak ubedit', zagipnotizirovat', zastavit' kogo ugodno. Malen'kaja kniga sil'nejshih primov gipnoza i vozdejstvija [A tough book on how to convince, hypnotize, get anyone. A small book of the strongest prims of hypnosis and influence]. Moskva: AST [in Russian].

11. Brader, Ted (2008). The Political Brain: The Role of Emotion in Deciding the Fate of the Nation - By Drew Westen. Political Psychology. Volume 29, Issue 4. Pp. 623-627. https://doi.org/10.1111/j.1467-9221.2008.00656.x [in English]. 
12. Brown, G. (1983). Discourse Analysis. Cambrige: Cambrige Univ. Press. [in English].

13. Ciftci, D. (2020). Political Marketing and New Media Election Campaigning: The Application of North Cyprus 2018 General Elections. Handbook of Research on New Media Applications in Public Relations and Advertising. Cyprus: Near East University, Department of Journalism, Faculty of Communication. Pp. 355-380 [in English].

14. Kovalevska, T., \& Kovalevska, A. (2020). Utilizing the Neurolinguistic Programming Technologies in Foreign languages Teaching Practice in Ukrainian Universities. Arab World English Journal: Special Issue on English in Ukrainian Context. Pp. 184-193. DOI: https://dx.doi.org/10.24093/awej/elt3.16 [in English].

15. Owen, Lord (2008). Swaying the swingers: how neuroscience influences voting behaviour. Brain. Volume 131, Issue 2. Pp. 591-595 https://doi.org/10.1093/brain/awm330 [in English].

16. Pinza, Mariela \& Flax Sabrina (2005). Marketing político. Durán Barba y JJ Rendón, radiografía de dos asesores clave en la construcción de los liderazgos de las derechas del siglo XXI. URL: https://www.celag.org/wpcontent/uploads/2015/08/Documento-4-marketing-pol\%C3\%ADtico.pdf (last access: 18.11.2020) [in Spanish].

17. Rendón, J. J. Power of one: JJ Rendon at TEDxUNPlaza 2013 (2013). URL: https://www.youtube.com/watch?v=o7k2icowDN8 (last access: 18.11.2020) [in English].

18. Victoroff, Jeff (2009). Drew Westen: The Political Brain: The Role of Emotion in Deciding the Fate of the Nation Bryan Caplan: The Myth of the Rational Voter: Why Democracies Choose Bad Policies. Democracy and Security. 5:2. Pp. 193197, DOI: 10.1080/17419160902973594 [in English].

19. Underwood, D., Sun, S. \& Welters, R.A.M.H.M. (2020). The effectiveness of plain packaging in discouraging tobacco consumption in Australia. Nat. Hum. Behav. 4. Pp. 1273-1284. https://doi.org/10.1038/s41562-020-00940-6

Ковалевська Анастасія Володимирівна, кандидат філологічних наук, доцент кафедри української та іноземних мов, Одеський регіональний інститут державного управління Національної академії державного управління при Президентові України (вул. Генуезька, 22, Одеса, Україна); e-mail: ana.kovalevskaya@gmail.com; https://orcid.org/0000-0002-1031-5546

Ковалевская Анастасия Владимировна, кандидат филологических наук, доцент кафедры украинского и иностранных языков, Одесский региональный институт государственного управления Национальной академии государственного управления при Президенте Украины (ул. Генуэзская, 22, Одесса, Украина); e-mail: ana.kovalevskaya@gmail.com; https://orcid.org/0000-0002-1031-5546 